\title{
METABOLIC SYNDROME OF HORSES DURING PHYSICAL ACTIVITY (DIAGNOSTICS CRITERIA)
}

\author{
I. A. Maksymovych, L. G. Slivinska \\ maksymovych@1vet.edu.ua
}

Lviv National University of Veterinary Medicine and Biotechnologies named after S. Z. Gzhytsky, 50 Pekarska str., Lviv 79010, Ukraine

The article shows the results of the study of biochemical blood indices in sports horses. It is shown that in horses after exercise the metabolic syndrome is developing which is a result of insufficient supply of organs and tissues of energy accompanied by development of dehydration, cytolysis syndrome, uremic syndrome, electrolyte imbalance.

Evaluation of cardiac output in horses must be performed during and after physical exertion, when latent disease manifests itself clinically. It is important to know the ways of flowing the course of metabolic processes that occur in the body of horses during physical activity of varying intensity. The most common reason for excluding horses from sports events is metabolic disorders and cardiovascular dysfunction.

The aim of the work was to investigate changes in biochemical blood parameters in sports horses after physical exertion. The material for research was horses, which are used in classical equestrian sports. In all horses the general analysis and biochemical parameters of blood, characterizing the functional state of the organs (heart, liver, kidneys) were investigated.

In horses for physical overstrain the most frequently the increased fatigue, dyspnea, tachycardia, and less frequently arrhythmias are registered. In sport horses after exercise dehydration (hyperproteinemia), uremic syndrome (increasing the concentration of urea and creatinine), cytolysis syndrome (activity increase of AST and $A L T$ ), electrolyte imbalance (decrease in serum sodium and potassium) develop. Installed tests can serve for early diagnosis of metabolic syndrome in horses for exercise.

Keywords: HORSES, METABOLIC SYNDROME, MYOCARDIAL DYSTROPHY, HEPATIC AND RENAL TESTS, ELECTROLYTE IMBALANCE, PHYSICAL ACTIVITY

\section{МЕТАБОЛІЧНИЙ СИНДРОМ У КОНЕЙ ЗА ФІЗИЧНОГО НАВАНТАЖЕННЯ (КРИТЕРІЇ ДІАГНОСТИКИ)}

\author{
I. А. Максимович, Л. Г. Слівінська \\ maksymovych@1vet.edu.ua
}

Львівський національний університет ветеринарної медицини

та біотехнологій імені С. З. Гжицького,

вул. Пекарська, 50, м. Львів, 79010, Україна

У статті проведено аналіз результатів дослідження біохімічних показників крові у спортивних коней. Показано, що в коней після фізичного навантаження розвивається метаболічний синдром, який є результатом недостатнього забезпечення органів і тканин енергією, що супроводжується розвитком дегідратащії, синдрому цитолізу, уремічного синдрому, дисбалансу електролітів.

Оцінку функиіонального стану серия в коней необхідно виконувати під час та після фізичного навантаження, коли латентний перебіг захворювання проявлясться клінічно. Важливим $є$ знання шляхів перебігу метаболічних прочесів, які відбуваються в організмі коней під час фізичного навантаження різноі інтенсивності. Найбільш поширеною причиною виключення коней зі спортивних змагань є метаболічні розлади та сериево-судинна дисфункиія.

Метою роботи було дослідити зміни біохімічних показників крові у спортивних коней після фізичного навантаження. Матеріалом для досліджень були коні, щзо використовуються у класичних видах кінного спорту. В усіх коней досліджували загальний аналіз та біохімічні показники крові, які характеризують функціональний стан органів (серия, печінки, нирок).

Найчастіше у коней за фізичного перетренування реєструється підвищена втомлюваність, задишка, помірна тахікардія, рідше - аритмії. У спортивних коней після фізичного навантаження розвивається дегідратація (гіперпротеїнемія), уремічний синдром (підвищення концентрації сечовини та кре- 
атиніну в сироватиі крові), синдром цитолізу (гіперферментемія АсАТ і АлАТ), дисбаланс електролітів (зниження в сироватиі крові вмісту натрію і калію). Встановлені тести можуть слугувати для ранньої діагностики метаболічного синдрому в коней за фізичного перетренування.

Ключові слова: КОНІ, МЕТАБОЛІЧНИЙ СИНДРОМ, МІОКАРДІОДИСТРОФІЯ, ПЕЧІНКОВИЙ ТА НИРКОВИЙ ТЕСТИ, ЕЛЕКТРОЛІТНИЙ ДИСБАЛАНС, ФІЗИЧНЕ НАВАНТАЖЕННЯ

\title{
МЕТАБОЛИЧЕСКИЙ СИНДРОМ В ЛОШАДЕЙ ПРИ ФИЗИЧЕСКОЙ НАГРУЗКЕ (КРИТЕРИИ ДИАГНОСТИКИ)
}

\author{
И. А. Максимович, Л. Г. Сливинская \\ maksymovych@1vet.edu.ua
}

Львовский национальный университет ветеринарной медицины

и биотехнологий имени С. З. Гжицкого,

ул. Пекарская, 50, г. Львов, 79010, Украина

В статье проведен анализ результатов исследования биохимических показателей крови у спортивных лошадей. Показано, что у лошадей после физической нагрузки развивается метаболический синдром, который является результатом недостаточного обеспечения органов и тканей энергией, сопровождается развитием дегидратации, синдрома иитолиза, уремического синдрома, дисбаланса электролитов.

Оиенку функиионального состояния сердиа у лошадей необходимо выполнять во время и после физической нагрузки, когда латентное течение заболеваний проявляется клинически. Немаловажным является знание путей течения метаболических прочессов, которые происходят в организме лошадей во время физической нагрузки различной интенсивности. Наиболее распространенной причиной исключения лошадей из спортивных соревнований являются метаболические расстройства и сердечно-сосудистая дисфункиия.

Целью работы было исследовать изменения биохимических показателей крови в спортивных лошадей после физической нагрузки. Материалом для исследований были лошади, которые используются в классических видах конного спорта. Во всех лошадей исследовали общий анализ и биохимические показатели крови, характеризующие функииональное состояние органов (сердиа, печени, почек).

Наиболее часто в лошадей при физическом перенапряжении регистрируется повышенная утомляемость, одышка, умеренная тахикардия, реже аритмии. В спортивных лошадей после физической нагрузки развивается дегидратация (гиперпротеинемия), уремический синдром (повышение концентрачии мочевины и креатинина в сыворотке крови), синдром цитолиза (гиперферментемия АсАТ и АлАТ), дисбаланс электролитов (снижение в сыворотке крови содержания натрия и калия). Установленные тесты могут служить для ранней диагностики метаболического синдрома у лошадей при физическом перенапряжении.

\section{КлючевЫе слова: ЛОШАДИ, МЕТАБОЛИЧЕСКИЙ СИНДРОМ, МИОКАРДИОДИСТРО- ФИЯ, ПЕЧЕНОЧНЫЙ И ПОЧЕЧНЫЙ ТЕСТЫ, ЭЛЕКТРОЛИТНЫЙ ДИСБАЛАНС, ФИЗИЧЕ- СКАЯ НАГРУЗКА}

The combination of the cardiovascular system diseases and metabolic disorders in the humane medicine has been known since the 1940 s. In the $1980 \mathrm{~s}$, this combination was determined by the term of the metabolic syndrome, which was included in the group of metabolic risk factors that occur simultaneously in one patient. Nowadays the term "metabolic syndrome" is common in the medical literature, but there are minor devergence about diagnostic criteria [25].

The physical activity of horses requires energy for a long time [34]. Under such condi- tions, a stable energy requirement is accompanied by metabolic disorders, and that causes dysfunction of the cardiorespiratory, endocrine and neuromuscular systems $[9,29]$.

The most common reason for excluding horses from sport competitions is colic [8], while other researchers have found that the main cause is metabolic disorders and disfunction cardiovascular system [35].

Active muscular activity promotes hypertrophy of the heart muscle. However, with the maximum muscular load, the increased use of adenosine triphosphate occurs, and the rate of supply with 
substrates and oxygen is insufficient. The reason for the development of myocardial dystrophy is the inconsistency between the energy expenditure in the functioning structures of the myocardium and their restoration, caused by significant increase in energy costs. According to the hypoxic theory, the pathological theory is caused by oxygen deficiency, and the neurodegenerative process connects myocardial dystrophy with the hypoxic effect of excess catecholamines [15].

However, due to physical activity, the electrolyte imbalance develops, as a result of which the processes of cellular respiration, oxidative phosphorylation and transmembrane exchange of cations are disturbed, which leads to a decrease in the formation of energy in the myocardium and the effectiveness of its use by functioning structures of the heart muscle [33]. Due to energy deficiency the myocardial dystrophy caused by metabolic disorders develops, which leads to the dystrophy and dysfunction of the heart muscle, accompanied by a disorder of electrical and metabolic processes in it [6]. The development of electrophysiological and functional dysfunction of the myocardium is caused by cellular acidosis, local inflammation and peroxidation, violation of ionic equilibrium, decrease in the synthesis of adenosine triphosphate [4].

Evaluation of the horse's heart functional state must be done during and after activity, when the latent course of the disease manifests itself clinically. It is important to know the ways of the metabolic processes flow that occur in a horse body during physical activity of different intensity [1].

The result of insufficient provision of physiological needs of tissues and organs during physical activities is a metabolic crisis, which can be manifested by fatigue, dehydration, oxidative or thermal stress $[35,20]$.

During physical activity the parameters of homeostasis change in horses, in particular their biochemical blood profile (electrolytes and acidbase balance) [3].

A number of studies have been conducted in to investigate changes in hematological parameters in horses' blood during physical activity [11, 23]. However, studies concerning horses excluded from the competition because of the metabolic disorders due to physical exertion are not adequately covered [8]. Therefore, the purpose of our work was to investigate changes in biochemical blood parameters of sport horses after physical activities.

\section{Materials and methods}

50 horses used in the classic equestrian sport of Ukrainian warmblood horses $(n=20)$, Hanoverian $(\mathrm{n}=15)$ and Westphalian $(\mathrm{n}=15)$ breeds horses were included into our research. Among the experimental animals there were 25 mares, 9 stallions and 16 geldings. The average age of horses was $8.4 \pm 0.71(3.5-16.0)$, the weight was $479.4 \pm 8.54 \mathrm{~kg}(350-605 \mathrm{~kg})$.

The daily diet of horses included: meadow grass $(6 \mathrm{~kg})$, oats $(6 \mathrm{~kg})$, wheat bran $(2 \mathrm{~kg})$, three times per day. Salt and water were available without restrictions.

The horses were examined clinically: the internal body temperature was measured, the pulse and respiration rate were counted, the heart auscultation was performed, the color of the mucous membranes and the time of capillaries filling were determined.

For all horses, a general analysis and biochemical blood indices were analyzed, characterizing the functional state of the organs (heart, liver, kidneys). Mares were not enceinte. All horses were dewormed and vaccinated, were in the same conditions of detention.

Studies were carried out immediately before physical activities and immediately afterwards. The duration of medium intensity of regular training was 1 hour: walk $-5 \mathrm{~min}$; rising trot $10 \mathrm{~min}$; walk $-5 \mathrm{~min}$; sitting trot $-10 \mathrm{~min}$; walk - 10 min; gallop with transition to a walk 10 min; walk - 10 min.

Blood samples of horses were taken from the jugular vein using injection needles $\varnothing 16 \times 40 \mathrm{~mm}$ into tubes ( $10 \mathrm{ml}$; Vacutest, Italy) without anticoagulant. The analysis of blood samples was carried out in the laboratory of the Department of Internal Animal Diseases and Clinical Diagnosis of Lviv National University of Veterinary Medicine and Biotechnologies named after S. Z. Gzhytsky.

To obtain blood serum, the tubes were centrifuged at $3000 \mathrm{rpm}$ for 10 minutes. The concentration of total protein, albumin, total bilirubin, glucose, urea, creatinine, total calcium, inorganic 
phosphorus, magnesium, activity of aspartate aminotransferase (AST), alanine aminotransferase (ALT), alkaline phosphatase (AP) and gamma-glutamyl transpeptidase (GGT) in the serum were determined using an automatic biochemical analyzer Mindray BS-120 (China) with reagents PZ Cormay S.A. (Poland). The content of potassium and sodium in the horses' serum was determined on a semi-automatic biochemical analyzer BioChem SA (USA) using reagents High Technology Inc., Production RD Walpole (USA).

Mathematical analysis of the obtained results was carried out using software Microsoft Office Excel by means of conventional methods of variation statistics with estimation of the mean $(\mathrm{M})$, its error (m), the probability by the Student's $t$-test.

\section{Results and discussion}

Most frequently increased fatigue, dyspnea, mild tachycardia $(46.4 \pm 1.20$ beats per minute, $36-68$ beats per minute) were observed in horses during physical activity, less frequently arrhythmias (sinus arrhythmia, supraventricular extrasystole) were observed.
The determination of total protein, albumin and globulin content allows determine the status (index) of body hydration, protein loss, or reduction of its synthesis [27]. Studies of humans and dogs have shown that protein is not an important energy substrate during physical activity. For horses the role of protein during physical activity is unknown, but it is assumed that carbohydrates and fat oxidations predominate in energy supply [26].

Serum total protein level horses of all breeds before physical activity was on the same level (table 1). After physical activity, the protein level increased in the blood of sport horses from three research groups, obviously, that is the result of dehydration. It was especially evident among horses of the Hanoverian $(\mathrm{P}<0.01)$ and Westphalian $(\mathrm{P}<0.05)$ breeds, while the horses of the Ukrainian warmblood horses had only a tendency of increasing (table 1). Significant dehydration was observed in for horses that were excluded from the competition due to the metabolic crisis $[3,10]$. After physical activity the content of albumin increased in blood of all research groups, but a significant difference was established only in the animals of the Hanoverian breed $(\mathrm{P}<0.05$; table 1$)$.

Table 1

Biochemical parameters of blood serum sport horses before and after exercise

\begin{tabular}{|c|l|c|c|c|c|c|c|c|}
\hline $\begin{array}{c}\text { Breeds } \\
\text { of horses }\end{array}$ & \multicolumn{1}{|c|}{ Groups } & $\mathrm{n}$ & $\begin{array}{c}\text { Total protein, } \\
\mathrm{g} / \mathrm{L}\end{array}$ & $\begin{array}{c}\text { Albumins, } \\
\mathrm{g} / \mathrm{L}\end{array}$ & $\begin{array}{c}\text { Total bilirubin, } \\
\mu \mathrm{mol} / \mathrm{L}\end{array}$ & $\begin{array}{c}\text { Glucose, } \\
\mathrm{mmol} / \mathrm{L}\end{array}$ & $\begin{array}{c}\text { Urea, } \\
\mathrm{mmol} / \mathrm{L}\end{array}$ & $\begin{array}{c}\text { Creatinine, } \\
\mu \mathrm{mol} / \mathrm{L}\end{array}$ \\
\hline \multirow{2}{*}{$\begin{array}{c}\text { Ukrainian } \\
\text { warmblood }\end{array}$} & Before exercise & 20 & $61.3 \pm 1.22$ & $37.8 \pm 0.78$ & $24.1 \pm 2.14$ & $5.5 \pm 0.22$ & $5.3 \pm 0.22$ & $132.8 \pm 5.42$ \\
\cline { 2 - 10 } & After exercise & 20 & $63.8 \pm 1.61$ & $38.0 \pm 0.56$ & $29.4 \pm 2.44$ & $5.2 \pm 0.21$ & $6.2 \pm 0.28^{*}$ & $162.3 \pm 5.91^{* *}$ \\
\hline \multirow{2}{*}{ Hanoverian } & Before exercise & 15 & $60.9 \pm 0.95$ & $36.2 \pm 0.84$ & $28.1 \pm 1.76$ & $5.5 \pm 0.13$ & $5.6 \pm 0.16$ & $127.7 \pm 6.86$ \\
\cline { 2 - 10 } & After exercise & 15 & $66.3 \pm 1.34^{* *}$ & $39.4 \pm 0.68^{*}$ & $29.1 \pm 1.81$ & $5.3 \pm 0.11$ & $5.9 \pm 0.28$ & $145.4 \pm 4.09^{*}$ \\
\hline \multirow{2}{*}{ Westphalian } & Before exercise & 15 & $61.2 \pm 1.55$ & $38.7 \pm 0.96$ & $26.6 \pm 1.24$ & $5.6 \pm 0.15$ & $5.1 \pm 0.20$ & $123.4 \pm 3.88$ \\
\cline { 2 - 10 } & After exercise & 15 & $67.1 \pm 2.07^{*}$ & $39.2 \pm 0.44$ & $32.5 \pm 1.69^{*}$ & $5.2 \pm 0.11^{*}$ & $5.6 \pm 0.15^{*}$ & $165.2 \pm 4.95^{* * *}$ \\
\hline
\end{tabular}

Note: here and in the next table * $-\mathrm{P}<0.05 ; * *-\mathrm{P}<0.01 ; * * *-\mathrm{P}<0.001$ compared to exercises.

The concentration of total bilirubin in serum of horses after physical activity increased. In horses of the Ukrainian warmblood horses on $22 \%$, the Hanoverian - $3.5 \%$ compared to the parameters before physical activity, and on $22.2 \%(\mathrm{P}<0.05)$ in the Westphalian breed (table 1). An increase in concentration of bilirubin in horses after physical activity may be the result of the development of cholestasis, which is obviously due to dyskinesia of the biliary tract during exercise [12], prooved by the tendency to the increased level of AP and GGT in serum of all research groups (table 2).
The gamma glutamine transferase (GGT) is considered to be a marker of oxidative stress [16, 37], which is a key in the development of metabolic imbalance [7, 17]. The oxidative stress developed $[5,14]$ in horses with a low training level during physical activity and an increased GGT serum level is the result of insufficient training of horses [21].

Serum glucose concentration tended to decrease in all experimental groups of animals after physical activity (table 1 ). In horses of the Ukrainian warmblood horses, its blood concentration decreased on $5.4 \%$, Hanoverian - by $3.6 \%$. In horses of the Westphalian breed the blood glu- 
Activity of enzymes of blood serum sport horses before and after exercise

\begin{tabular}{|l|l|c|c|c|c|c|}
\hline \multicolumn{1}{|c|}{$\begin{array}{c}\text { Breeds } \\
\text { of horses }\end{array}$} & \multicolumn{1}{c|}{ Groups } & $\mathrm{n}$ & AST, U/L & ALT, U/L & AP, U/L & GGT, U/L \\
\hline \multirow{2}{*}{$\begin{array}{l}\text { Ukrainian } \\
\text { warmblood }\end{array}$} & Before exercise & 20 & $257.2 \pm 10.12$ & $6.4 \pm 0.54$ & $112.2 \pm 8.37$ & $13.5 \pm 0.90$ \\
\cline { 2 - 8 } & After exercise & 20 & $300.0 \pm 16.01 *$ & $7.3 \pm 1.05$ & $116.5 \pm 9.69$ & $14.2 \pm 1.25$ \\
\hline \multirow{2}{*}{ Hanoverian } & Before exercise & 15 & $257.2 \pm 7.01$ & $5.5 \pm 0.34$ & $111.3 \pm 5.55$ & $11.0 \pm 0.73$ \\
\cline { 2 - 8 } & After exercise & 15 & $292.9 \pm 8.13 * * *$ & $6.5 \pm 0.45$ & $120.3 \pm 6.60$ & $12.2 \pm 0.95$ \\
\hline \multirow{2}{*}{ Westphalian } & Before exercise & 15 & $259.7 \pm 11.27$ & $5.2 \pm 0.35$ & $106.9 \pm 5.01$ & $12.8 \pm 0.75$ \\
\cline { 2 - 8 } & After exercise & 15 & $302.5 \pm 6.89 * *$ & $8.7 \pm 0.95 * *$ & $109.2 \pm 7.60$ & $13.8 \pm 1.21$ \\
\hline
\end{tabular}

cose concentration was reduced by $7.1 \%(\mathrm{P}<0.05)$ after physical activity, compared to the values before the activity (table 1).

Determination of urea and creatinine blood concentration is used to assess glomerular filtration of the kidneys [2]. For horses of the Hanoverian breed, the urea content tended to increase (by $5.4 \%$ ), while in horses of the Ukrainian warmblood and Westphalian breeds it was increased significantly on $17.0 \%(\mathrm{P}<0.05)$ and $9.8 \%(\mathrm{P}<0.05$; table 1$)$.

The creatinine concentration in the blood of horses of three research groups increased after physical activity: horses of the Ukrainian warmblood horses on $22.2 \%(\mathrm{P}<0.01)$, Hanoverian $13.9 \%(\mathrm{P}<0.05)$ and Westphalian breeds on $33.9 \%$ $(\mathrm{P}<0.001$; table 1$)$.

Creatinine is a metabolite of creatin found in high concentrations in tissues that have a high energy demand, including skeletal muscles (98\% of the total body creatin pool) $[27,30]$.

Physical activity causes an increase in the level of free oxygen radicals [32] that have a vasoconstrictive effect, reduces the rate of glomerular filtration by direct inactivation of cyclooxygenase in epithelial cells [22]. Physical activity also leads to an increase in the content of endothelin, catecholamines, angiotensin II, cytokines [32] that release mediators, which promote the development of kidney ischemia [30] and the development of acute renal failure [13]. So, in terms of physical activity, glomerular filtration of the kidneys is disturbed in horses, and the uremic syndrome develops.

According to the results of our study sport horses have significantly increased serum activity of AST after physical activity: Ukrainian $(\mathrm{P}<0.05)$, Hanoverian $(\mathrm{P}<0.001)$ and Westphalian $(\mathrm{P}<0.01$; table 2) breeds. Serum level of ALT also tended to increase after physical activity in horses of the
Ukrainian warmblood and Hanoverian breeds (table 2), whereas in Westphalian horses the increase was significant $(7.8 \%$; $<<0.01)$.

The increased activity of AST and ALT in serum of horses is directly related to a violation of the permeability of the muscle cell membranes, it can be registered in case of myopathy during physical activity. However, the enzymes activity in the horses' blood depends on the level of physical preparation, intensity and duration of the load [36].

It is possible that the increase in activity of AST in the blood serum of horses after physical activity can be the result of a violation of the permeability of the membranes of cardiomyocytes due to damage to the myocardium [31].

Our previous studies have established [18] that the total calcium and inorganic phosphorus serum content in horses after a moderate-intensity activity tended to decrease. Physical activity of sport horses did not affect the exchange of magnesium in blood.

In sporting horses, after exercise the natrium blood serum content significantly decreases: in Ukrainian warmblood on $5.6 \%(\mathrm{P}<0.05)$, Hanoverian $-9.2 \%(\mathrm{P}<0.01)$ and Westphalian breeds on $13.3 \%(\mathrm{P}<0.001)$. The potassium serum content in the Hanoverian horses after the physical activity had the tendency to decrease (on $8.5 \%$ ), whereas in the horses of the Ukrainian warmblood and Westphalian breeds the decrease was significant on $10.5 \%(\mathrm{P}<0.05)$ and $19 \%(\mathrm{P}<0.01)$, respectively. Obviously that after physical activity, the reduction of sodium and potassium in serum of horses is due by the loss of electrolytes with sweat, which also causes the development of electrolyte disbalance [18].

During activity in horses with metabolic imbalance, factors that are not related to feeding are more important. These include the loss of electro- 
lytes with sweat, resulting in a violation of the neuromuscular transmission, and loss of water with sweat (dehydration) causes hemodynamic disturbances and impares supply of the oxygen and substrates, to the heart muscle [17]. At the same time, the loss of water and electrolytes leads to the development of progressive metabolic alkalosis [19, 24, 28].

The results of our studies showed that an increase in the total protein content (dehydration), urea and creatinine (a violation of the functional state of the kidneys, which is characteristic of development uremic syndrome), a decrease in sodium and potassium levels (electrolyte imbalance), an increase in AST activity (cytolysis syndrome) can serve for early diagnosis of metabolic syndrome in horses during physical activity.

\section{Conclusions}

1. Horse's metabolic syndrome is the result of insufficient provision of organs and tissues with energy, accompanied by the development of dehydration, cytolysis, nephrotic syndrome, electrolyte imbalance.

2. Sport horses have dehydration (hyperproteinemia), uremic syndrome (increased urea and creatinine concentration), cytolysis syndrome (increased activity of AST and ALT) after physical activity.

3 . The serum levels of sodium and potassium in horses decrease after physical activity due to the loss of electrolytes with sweat and the development of electrolyte imbalance.

Perspectives for further research. Develop and test circuit correction of metabolic syndrome in sport horses for exercise. The focus will be on the positive effects of cardioprotectors.

1. Bergero D., Assenza A., Caola G. Contribution to our knowledge of the physiology and metabolism of endurance horses. Livest. Prod. Sci., 2005, vol. 92, pp. 167-176.

2. Braun J. P., Lefebvre H. P., Watson A. D. J. Creatinine in the dog: a review. Vet. Clin. Pathol., 2003, vol. 32, pp. 162-179.

3. Castejon F., Trigo P., Muñoz A., Riber C. Uric acid responses to endurance racing and relationships with performance, plasma biochemistry and metabolic alterations. Equine Vet. J., 2006, vol. 36, pp. 70-73.

4. Chernaya M. A., Dementieva I. I., Morozov Yu. A., Gladysheva V. G. Cardiospecific biomarkers in cardiology and cardiosurgery. Part 1 . General characteristics of biomarkers. Cardiology and cardiovascular surgery, 2010, no. 3, pp. 26-33. (in Russian)

5. Demircan S., Yazici M., Durna K., Kilicaslan F., Demir S., Pinar M., Gulel O. The importance of gamma-glutamyltransferase activity in patients with coronary artery disease. Clin. Cardiol., 2009, vol. 32, pp. 220-225.

6. Dimopoulos K., Diller G. P., Giannakoulas G., Petraco R., Chamaidi A., Karaoli E., Mullen M., Swan L., Piepoli M. F., Poole-Wilson P. A., Francis D. P., Gatzoulis M. A. Anemia in adults with congenital heart disease relates to adverse outcome. J. Am. Coll. Cardiol., 2009, vol. 22, pp. 2093-2100.

7. Fernando J. G., Claudio C. Z., Leonardo R. S., Lucia P. S., Denise V. M. Possible relationship between performance and oxidative stress in endurance horses. J. Equine Vet. Sci., 2009, vol. 29, pp. 206-212.

8. Fielding C. L., Magdesian K. G., Rhodes D. M., Meier C. A., Higgins J. C. Clinical and biochemical abnormalities in endurance horses eliminated from competition for medical complications and requiring emergency medical treatment: 30 cases (2005-2006). J. Vet. Emerg. Crit. Care, 2009, vol. 19, pp. 473-478.

9. Flaminio M. J., Rush B. R. Fluid and electrolyte balance in endurance horses. Vet Clin. N. Am.: Equine Pract., 1998, vol. 14, pp. 147-158.

10. Francesca S., Harold C. S., Kenneth W. H., Raymond J. G., Eduard J. C. Electrolyte supplementation for endurance horses: effects of fluid losses and performance. AAEPProc, 2007, vol. 42, pp. 82-85.

11. Golovacha V. I., Piddubnyak A. V., Chub O. V. Erythrocytopoesis indexes in mares of the Ukrainian uprider breed before and after parturition. Scientific notes $U O$ $V G A V M, 2017$, vol. 53, no. 2, pp. 119-123. (in Russian)

12. Golovacha V. I., Ushkalov V. O., Zhyla I. A., Kutsan O. T., Bobrovska N. V. Diagnosis and correction of hepatorenal syndrome in horses with gastric fodder toxicosis. Bulletin of the Bila Tserkva State Agrarian University, 2005, vol. 33, pp. 19-30. (in Ukrainian)

13. Hisanaga S., Ueno N., Inagaki H., Tokura T., Uezono S., Yokota N., Fujimoto S., Eto T. Exercise-induced acute renal failure associated with renal vasoconstriction. Nippon Jinzo Gakki Shi., 1999, vol. 41, 406-412.

14. Kinnunen S., Atalay M., Hyyppa S., Lehmuskero A., Hanninen O., Oksala N. Effects of prolonged exercise on oxidative stress and antioxidant defense in endurance horse. J. Sports Sci. Med., 2005, vol. 4, pp. 415-421.

15. Kushakovsky M. S. Metabolic diseases of the heart (Myocardia - myocardosis - myocardial dystrophy - cardiomyopathy). Saint Petersburg, Foliant, 2000. 127 p. (in Russian)

16. Lee D.H., Blomhoff R., Jacobs D. R. Is serum gamma glutamyltransferase a marker of oxidative stress? Free Radic. Res., 2004, vol. 38, pp. 535-539.

17. Lee D. H., Jacobs D. R. Association between serum gamma glutamyltransferase and C-reactive protein. Atherossclerosis, 2005, vol. 178, pp. 327-330. 
18. Maksymovych I. A. Exchange of electrolytes in sports horse for exercise. Scientific Messenger of Lviv National University of Veterinary Medicine and Biotechnologies named after S. Z. Gzhytsky, 2017, vol. 19, no. 77, pp. 100-104. (in Ukrainian)

19. McKeever K. N. Body fluids and electrolytes: responses to exercise and training. In: Equine sports medicine and surgery. Hinchcliff K. W., Kaneps A. J., Geor R. J. (Eds.). Saunders, Philadelphia, 2004, pp. 854-871.

20. Niedźwiedź A., Maksymovych I., Slivinska L., Kubiak K. Metabolic syndrome in horses. Scientific notes UO VGAVM, 2017, vol. 53, no. 2, pp. 106-110. (in Russian)

21. Noleto P. G., Cubas J. P. C., Barbosa F. C., Guimarães E. C., Mundim A. V. Biochemical profile of polo horses in training phase and those players of official competition. Comp. Clin. Pathol., 2016, vol. 25, pp. 911-915.

22. Ohtra T., Sakano T., Igarashi T., Itami N., Ogawa T. Exercise-induced acute renal failure associated with renal hypouricaemia: Results of a questionnaire-based survery in Japan. Nephrol. Dial. Transplant., 2004, vol. 19, pp. 1447-1453.

23. Piccione G., Arcigli A., Costa A., Percipalle M., Caola G. Acid-base balance assessment during exercise in the show jumping horse. Folia Vet., 2003, vol. 47, no. 2, pp. 91-94.

24. Piccione G., Vazzana I., Giannetto G., Gianesella M., Ferrantelli V. Modification of some hematological and hematochemical parameters in horse during long distance rides. Res. J. Vet. Sci., 2008, vol. 1, no. 1 , pp. 37-43.

25. Poryadin G. V., Oskolok L. N. Pathophysiological aspects of the metabolic syndrome. Therapeutics, 2011, no. 4, pp. 1-10. (in Russian)

26. Pösö Reeta A., Hyyppa S., Geor R. J. Metabolic responses to exercise and training. In: Equine sports medicine and surgery. Hinchcliff K. W., Kaneps A., Geor R. J. (Eds.), Saunders, China, 2004, pp. 771-792.

27. Rose R. J., Hodgson D. R. Hematology and biochemistry. In: Principles and practice of equine sports medicine: The athletic horse. Hodgson D. H., Rose R. J., Saunders W. B. (Eds.). Philadelphia, Company, 1994, pp. 63-78.
28. Rose R. J., Ilkiw J. E., Martin C. Blood-gas, acis-base and haematological values in horses during an endurance ride. Equine Vet. J., 1979, vol. 11, pp. 56-59.

29. Schott H. C., $2^{\text {nd }}$, Marlin D. J., Geor R. J., Holbrook T. C., Deaton C. M., Vincent T., Dacre K., Schroter R. C., Jose-Cunilleras E., Cornelisse C. J. Changes in selected physiological and laboratory measurements in elite horses competing in a $160 \mathrm{~km}$ endurance ride. Equine Vet. J., 2006, vol. 36, pp. 37-42.

30. Sewell D. A., Harris R. C. Effects of creatinine supplementation in the Thoroughbred horse. Equine Vet. J. Suppl., 1995, vol. 18, pp. 239-242.

31. Singh T. P., Nigam A. K., Gupta A. K., Singh B. Cardiac Biomarkers: When to Test? - Physician Perspective. JIACM, 2011, vol. 12, no. 2, pp. 117-121.

32. Snaders L. R. Exercise-induced acute renal failure associated with ibuprofen, hydrocholorothiazide and triamterene. J. Am. Soc. Nephrol., 1995, vol. 5, pp. 2020-2023.

33. Tarmonova L. Yu., Shutov A. M. Anemia and renal dysfunction in elderly and senile patients with diastolic heart failure. Clinical gerontology, 2007, vol. 13, no. 11, pp. C. 8-12. (in Russian)

34. Treiber K. H., Hess T. M., Kronfeld D. S., Boston R. C., Geor R. J., Friere M., Silva A. M., Harris P. A. Glucose dynamics during exercise: dietary energy sources affect minimal model parameters in trained Arabian geldings during endurance exercise. Equine Vet. J., 2006, vol. 36, pp. 631-636.

35. Trigo P., Castejon F., Riber C., Muñoz A. Use of biochemical parameters to predict metabolic elimination in endurance rides. Equine Vet. J., 2010, vol. 42, no. 38, pp. 142-146.

36. Wanderley E. K., Bem B. C. S., Melo S. K. M., Gonzales J. C., Manso H. E. C. C., Manso Filho H. C. Hematological and biochemical changers in Mangalarga Marchador horses after an hour-beat gait challenge in three different distances. J. Equine Vet. Sci., 2015, vol. 35, pp. 259-263.

37. Yang H. K., Hong K. M., Seck M. S., Kim I. J., Yong K. K. The association of serum gamma glutamyltransferase with components of the metabolic syndrome in the Korean adults. Diabetes Res. Clin. Pract., 2007, vol. 77, pp. 306-313. 